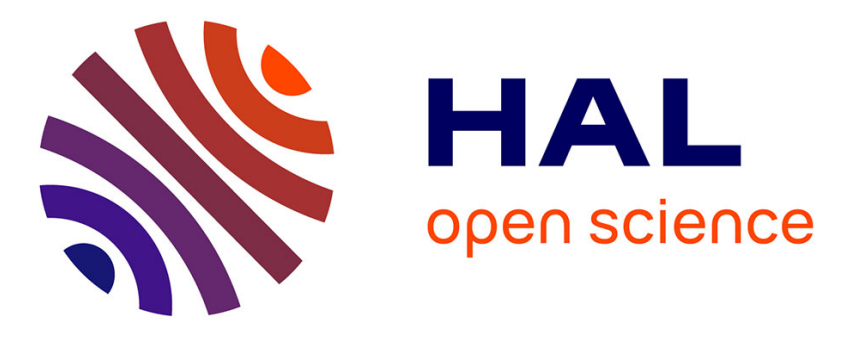

\title{
Evidence and effects of fluid circulation on organic matter in intramontane coalfields (Massif Central, France)
}

Yoann Copard, Jean-Robert Disnar, Jean-François Becq-Giraudon, Mohammed Boussafir

\section{To cite this version:}

Yoann Copard, Jean-Robert Disnar, Jean-François Becq-Giraudon, Mohammed Boussafir. Evidence and effects of fluid circulation on organic matter in intramontane coalfields (Massif Central, France). International Journal of Coal Geology, 2000, 44, pp.49-68. 10.1016/S0166-5162(99)00049-X . hal00091231

\section{HAL Id: hal-00091231 \\ https://hal-insu.archives-ouvertes.fr/hal-00091231}

Submitted on 7 May 2013

HAL is a multi-disciplinary open access archive for the deposit and dissemination of scientific research documents, whether they are published or not. The documents may come from teaching and research institutions in France or abroad, or from public or private research centers.
L'archive ouverte pluridisciplinaire HAL, est destinée au dépôt et à la diffusion de documents scientifiques de niveau recherche, publiés ou non, émanant des établissements d'enseignement et de recherche français ou étrangers, des laboratoires publics ou privés. 


\title{
Evidence and effects of fluid circulation on organic matter in intramontane coalfields (Massif Central, France)
}

\author{
Y Copard ${ }^{\mathrm{a}}$ J.R Disnar ${ }^{\mathrm{a} 1}$ J.-F Becq-Giraudon ${ }^{\mathrm{b} 2}$ M Boussafir ${ }^{\mathrm{a}}$
}

- $\quad{ }^{a}$ UMR 6531 and FR 09 du CNRS, Université d'Orléans, 45067 Orléans Cedex, France

- $\quad$ b BRGM, DR/LGM, Av. Claude Guillemin, B.P. 6009, 45060 Orléans, France

\begin{abstract}
Recent evidence for a Late Carboniferous hydrothermal event responsible for $\mathrm{Au}-\mathrm{As}$ mineralization within the Variscan belt of the French Massif Central adds a supplementary episode to the already rather complex thermal history of this area. To better understand this history, 45 coal samples from various sites in the Massif Central were studied petrographically (reflectance analysis) and geochemically (Rock-Eval pyrolysis). The results of this study suggest that the studied coal was buried to $1500 \mathrm{~m}$ and that the coalification took place within $25 \mathrm{Ma}$, probably ending at the boundary between the Early and Late Permian (marked by the Saalic orogeny). Two thermal end-members basins were identified: (i) the Carboniferous of Bosmoreau-les-Mines (Limousin) and West Graissessac (Montagne Noire) showing geothermal paleoflow values between 150 and $180 \mathrm{~mW} \mathrm{~m}^{-2}$, and (ii) the Stephanian of Argentat and Détroit de Rodez (SW Massif Central) with values estimated at between 100 and $120 \mathrm{~mW} \mathrm{~m}^{-2}$. By plotting the $T_{\max }$ and $R_{\mathrm{o}}$ values on a diagram, the samples were grouped into two populations, the first showing a positive correlation between $R_{\mathrm{o}}$ and $T_{\max }$ and the second with higher $T_{\max }$ values than expected after $R_{\mathrm{o}}$ values. Selected samples of the second group are also characterized by a high Oxygen Index (OI) that increases with $T_{\max }$. These divergence between $R_{\mathrm{O}}$ and $T_{\max }$ associated with a high OI may be the result of the circulation of slightly oxidizing hot fluids subsequent to coalification. The other kind of $R_{0}-T_{\max }$ divergence seems to be linked to local, particularly high thermal activity, especially in Graissessac and Bosmoreau basins. It is interpreted as being due to a difference in response of these two maturity indicators, respectively to the intensity and duration of the thermal events (e.g., short-lived hydrothermal circulation and thermal domes of regional extent).
\end{abstract}

\section{Keywords}

- Stephanian;

- Massif Central;

- coalification anomaly;

- Rock-Eval;

- vitrinite reflectance;

- hot fluid;

- thermal dome

\section{Introduction}

After the Devonian-Visean, the Variscan belt of the French Massif Central was successively subjected to crustal thickening then thinning (Faure and Becq-Giraudon, 1993; Faure, 1995; Faure et al., 1997). Crustal instability following thickening was first marked by a Late Variscan (350 Ma) strike-slip event, and then by a Middle-Late Carboniferous extensional episode (Leloix, 1998). Sedimentary basins then developed along major faults such as the Sillon Houiller Fault and the Argentat Fault (Letourneur, 1953; Marest, 1985; Gelard et al., 
1986; Faure and Becq-Giraudon, 1993; Genna et al., 1998). The basement lineaments commonly controlling the distribution and paleogeography of these basins (Faure, 1995) were preferentially adopted as pathways by high-temperature hydrothermal fluids, particularly those responsible for $\mathrm{Au}-\mathrm{As}$ mineralization within the French Massif Central (Bouchot et al., 1997; Roig et al., 1997). These same fluids probably also affected sediments in basins such as Blanzy-Montceau (Berquer-Gaboreau, 1986) and Meisseix-Singles (Robert et al., 1988). For example, at Blanzy-Montceau, Golitsyn et al. (1997)noted an increase in the coal rank along a single layer towards an active fault that would have controlled heat flow by draining heatbearing fluids.

One the initial aims of the present study was to determine whether the hydrothermal fluids which circulated during the Middle-Late Carboniferous (Roig et al., 1997) could have affected the coals in the French Massif Central. Accordingly, in this paper, we discuss the thermal activity of the basins analysed (Fig. 1), beginning with the maximum depth of burial of the Carboniferous succession and the duration of coal maturation in the Carboniferous and Permian by the use of two parameters of OM rank, i.e., vitrinite reflectance $R_{\mathrm{o}}(\%)$ and $T_{\max }$ $\left({ }^{\circ} \mathrm{C}\right)$. Then, we estimated the maximum paleotemperatures experienced by the coal during burial and examined the nature and origin OM maturity anomalies to determine whether they could have been caused by hydrothermal circulations.

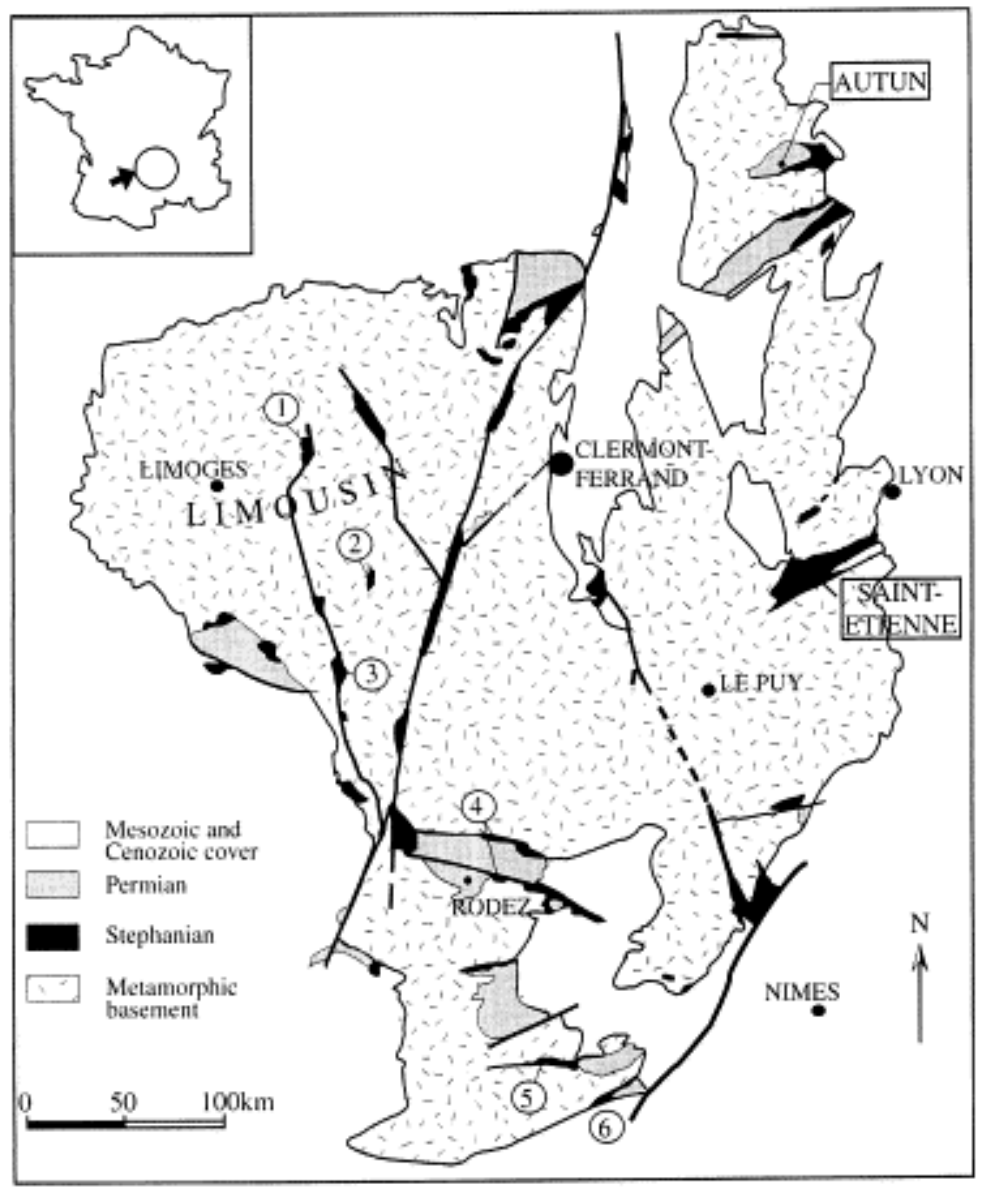

Fig. 1. General map of the Massif Central showing the location of the Carboniferous basins from which the analysed coal samples were collected (adapted from Becq-Giraudon, 1984). 1: Bosmoreaules-Mines, 2: Lapleau-Maussac, 3: Argentat, 4: Détroit de Rodez, 5: Graissessac, 6: Roujan-Neffiès. 


\section{Samples and methods}

\subsection{Samples}

The study was based on the analysis of 45 grab coal samples collected from outcrop in six Carboniferous intramontane basins, namely: (1) Bosmoreau-les-Mines at the northern end of the Argentat Fault, (2) Lapleau-Maussac, (3) the Carboniferous of Argentat in Bas-Limousin, (4) Détroit de Rodez, (5) Graissessac, the western continuation of the Permian Lodève basin, and (6) Roujan-Neffiès to the south of the metamorphic domain of the Montagne Noire (Fig. $1)$.

\subsection{Methods}

Two rank parameters were recorded for all the samples, $R_{\mathrm{o}}(\%)$ and $T_{\max }\left({ }^{\circ} \mathrm{C}\right)$ of Rock-Eval pyrolysis. The reflectance was measured using grain polished sections according to the standard method developed by the International Committee of Coal Petrology (ICCP) using a reflected light microscope (LEITZ MPV II) equipped with a monochromator and a photometer. Qualitative petrographic examinations, such as microfracture and oxidation studies, were carried out on whole-rock polished sections.

Some samples (A1, A3 from Argentat and Sé1, Sé2 from Graissessac) were analysed under a scanning electron microscope in backscattered electron mode (SEM/BE) to test for the presence of chemical elements or minerals characteristic of hydrothermal circulation (EDS point analysis) and to examine the fractures within the vitrinite particles.

Rock-Eval pyrolysis was carried out using the Rock-Eval® 6 device of Vinci Technologies according to the conditions given in Table 1. $T_{\max }$ corresponds to the temperature recorded for the S2 pyrolysis peak, i.e., when the emission of hydrocarbon-bearing compounds is at its maximum during thermal cracking of kerogen under inert atmosphere, in linear programming of temperature (Espitalié et al., 1985a, Espitalié et al., 1985b and Espitalié et al., 1985c). In addition to $T_{\max }$, pyrolysis provides values of Total Organic Carbon (TOC) (\%), Oxygen Index (OI expressed in $\mathrm{mg} \mathrm{CO}_{2} / \mathrm{g}$ TOC) and Hydrogen Index (HI expressed in $\mathrm{mg} \mathrm{HC/g}$ TOC). $\mathrm{HI}$ and $\mathrm{OI}$, corresponding respectively to the quantities of hydrocarbons and $\mathrm{CO}_{2}$ released during pyrolysis, in relation to TOC, are proportional to the hydrogen and oxygen contents of the OM ( Espitalié et al., 1985a, Espitalié et al., 1985b and Espitalié et al., 1985c; Lafargue et al., 1996).

Table 1. Experimental conditions for Rock-Eval® 6 pyrolysis

\section{Initial temperature}

$\left({ }^{\circ} \mathbf{C}\right)$

pyrolysis 300

oxidation 400
Final temperature

$\left({ }^{\circ} \mathbf{C}\right)$

800

850
Temperature programming $25^{\circ} \mathrm{C} / \mathrm{min}$ $25^{\circ} \mathrm{C} / \mathrm{min}$ 


\section{Results}

The $R_{\mathrm{O}}$ measurements and pyrolysis results are given in Table 2. We will not discuss here the TOC values which, for the disseminated samples collected at outcrop, simply confirm whether we are dealing with coal sample from a seam or dispersed OM.

Table 2. Rock-Eval pyrolysis and $R_{\mathrm{o}}$ results

\begin{tabular}{|c|c|c|c|c|c|c|c|}
\hline Basin & Sample & $\begin{array}{l}R_{\mathbf{0}} \\
(\%)\end{array}$ & $\begin{array}{l}\text { Standard } \\
\text { deviation }\end{array}$ & $\begin{array}{l}T_{\max } \\
\left({ }^{\circ} \mathbf{C}\right)\end{array}$ & $\underset{\text { (mgHC/gTOC) }}{\text { HI }}$ & $\begin{array}{c}\text { TOC } \\
(\%)\end{array}$ & $\begin{array}{c}\text { OI } \\
\left(\mathrm{mgCO}_{2} / \mathrm{gTOC}\right)\end{array}$ \\
\hline \multirow[t]{4}{*}{ Argentat } & A.1 & 0.64 & 0.084 & 446 & 25 & 25 & 70.35 \\
\hline & A.2 & 0.65 & 0.102 & 447 & 73 & 73 & 44.13 \\
\hline & A.3 & 0.69 & 0.069 & 560 & 9 & 19 & 96.23 \\
\hline & A. $3^{\prime}$ & 0.60 & 0.083 & 506 & 9 & 20 & 62.3 \\
\hline \multirow[t]{2}{*}{$\begin{array}{l}\text { Bosmoreau- } \\
\text { les-Mines }\end{array}$} & $B .1$ & 1.37 & 0.094 & 564 & 25 & 70.74 & 2.42 \\
\hline & B. 3 & 1.43 & 0.081 & 562 & 36 & 38.77 & 2.22 \\
\hline \multirow[t]{4}{*}{$\begin{array}{l}\text { Lapleau- } \\
\text { Maussac }\end{array}$} & $L M 1$ & 1.06 & 0.100 & 486 & 84 & 73.8 & 5.19 \\
\hline & $L M 2$ & 1.03 & 0.088 & 470 & 121 & 52.65 & 4.69 \\
\hline & $L M 3$ & 1.20 & 0.087 & 494 & 94 & 46.67 & 10.89 \\
\hline & $L M 4$ & 0.83 & 0.056 & 500 & 14 & 7.52 & 81.13 \\
\hline \multirow{6}{*}{$\begin{array}{l}\text { Détroit de } \\
\text { Rodez, North } \\
\text { border }\end{array}$} & & & & & & & \\
\hline & E1 & 0.61 & 0.065 & 437 & 189 & 62.16 & 6.52 \\
\hline & E3 & 0.68 & 0.090 & 437 & 62 & 15.02 & 53.36 \\
\hline & $E 4$ & 0.67 & 0.080 & 434 & 126 & 43.95 & 37.90 \\
\hline & Poul & 0.66 & 0.075 & 430 & 186 & 28.02 & 31.1 \\
\hline & Роu2 & 0.61 & 0.063 & 444 & 207 & 37.64 & 7.70 \\
\hline \multirow{9}{*}{$\begin{array}{l}\text { Détroit de } \\
\text { Rodez, South } \\
\text { border }\end{array}$} & & & & & & & \\
\hline & Berl & 0.71 & 0.059 & 437 & 175 & 52.02 & 7.19 \\
\hline & Ber2 & 0.80 & 0.115 & 441 & 49 & 20.55 & 57.56 \\
\hline & Ber3 & 0.92 & 0.181 & 444 & 57 & 51.92 & 33.26 \\
\hline & Ber4 & 0.77 & 0.075 & 485 & 60 & 63.59 & 15.18 \\
\hline & Ber4' & 0.77 & 0.74 & 449 & 31 & 4.17 & 49.18 \\
\hline & Gal & 0.73 & 0.084 & 438 & 217 & 46.1 & 8.94 \\
\hline & $A y 1$ & 0.63 & 0.074 & 447 & 18 & 36.72 & 67.66 \\
\hline & Mél & 1.05 & 0.078 & 442 & 213 & 40.38 & 7.38 \\
\hline \multirow[t]{3}{*}{$\begin{array}{l}\text { Roujan- } \\
\text { Neffiès }\end{array}$} & Ro-Né1 & 1.42 & 0.099 & 475 & 63 & 23.03 & 10.86 \\
\hline & Ro-Né2 & 1.45 & 0.079 & 489 & 68 & 8.01 & 12.45 \\
\hline & Ro-Né3 & 1.35 & 0.044 & 533 & 18 & 6.17 & 61.42 \\
\hline East & Sé1 & 1.41 & 0.108 & 477 & 150 & 44.59 & 2.91 \\
\hline
\end{tabular}




\begin{tabular}{|c|c|c|c|c|c|c|}
\hline Basin & Sample & $\begin{array}{cc}R_{0} & \text { Standard } \\
(\%) & \text { deviation }\end{array}$ & $\begin{array}{l}T_{\max } \\
\left({ }^{\circ} \mathrm{C}\right)\end{array}$ & $\begin{array}{c}\text { HI } \\
\text { (mgHC/gTOC) }\end{array}$ & $\begin{array}{c}\text { TOC } \\
(\%)\end{array}$ & (mgC \\
\hline \multicolumn{7}{|l|}{ Graissessac } \\
\hline & Sé2 & $\begin{array}{ll}1.31 & 0.087\end{array}$ & 536 & 20 & 46.73 & 55.58 \\
\hline & Sé3 & 1.360 .079 & 477 & 101 & 13.15 & 4.17 \\
\hline & Sé4.1 & 1.400 .067 & 473 & 118 & 17.53 & 4.40 \\
\hline & Sé4;2 & 1.400 .056 & 472 & 141 & 25.73 & 2.29 \\
\hline & Sé4.3 & 1.460 .073 & 492 & 67 & 48.38 & 6.99 \\
\hline & Sé5 & 1.460 .065 & 481 & 128 & 47.71 & 4.44 \\
\hline & Sé6 & 1.450 .068 & 514 & 36 & 47.55 & 41.53 \\
\hline & Rayl & 1.460 .111 & 490 & 63 & 50.01 & 9.9 \\
\hline & Moul & 1.390 .094 & 513 & 33 & 54.67 & 57.9 \\
\hline & $R G 1$ & 1.250 .085 & 477 & 128 & 52.34 & 5.29 \\
\hline & $R G 2$ & 1.200 .102 & 560 & 11 & 26.4 & 75.34 \\
\hline & Sal & 1.490 .095 & 605 & 5 & 32.92 & 67.09 \\
\hline & $S a 1^{\prime}$ & 1.450 .064 & 515 & 10 & 3.55 & 60.68 \\
\hline & $\begin{array}{l}\text { Roc- } \\
\text { Campl }\end{array}$ & 1.480 .086 & 553 & 29 & 48.85 & 50.11 \\
\hline \multirow[t]{3}{*}{$\begin{array}{l}\text { West } \\
\text { Graissessac }\end{array}$} & Pal & 2.050 .071 & 610 & 10 & 51.77 & $44.5 \mathrm{C}$ \\
\hline & Cadl & 2.050 .064 & 604 & 19 & 50.96 & 40.84 \\
\hline & Cad2 & 2.150 .104 & 600 & 15 & 38.93 & 37.54 \\
\hline
\end{tabular}

\subsection{Vitrinite reflectance}

The vitrinite reflectance was systematically measured on telocollinite, a submaceral of collinite (Fig. 2a). The coal from the Argentat and Détroit de Rodez basins (Fig. 1) shows $R_{\mathrm{o}}$ values between 0.6 and $1.05 \%$ (Table 2) which, according to the North-American classification (ASTM standard), coincides with a rank of high volatile B to A bituminous. Apart from samples Ber3 $\left(R_{\mathrm{o}} 0.92 \%\right)$ and Mé1 $\left(R_{\mathrm{o}} 1.05 \%\right)$ that are characterized by a relatively high $R_{\mathrm{o}}$ attributed to recent meteoric weathering, the Détroit de Rodez coal shows a relatively homogeneous degree of maturity with, however, a slightly higher rank near the southern border. The maturity of these samples is very similar to that of coal from the Decazeville mine (Détroit de Rodez; 0.6 to $0.8 \%$, Ligouis, 1988). With reflectance values between 0.6 and $0.69 \%$, the Argentat coal is given the rank of high volatile B bituminous. Samples LM1, LM2 and LM3 from the base of the Carboniferous of Lapleau-Maussac have reflectance values greater than $1 \%$, with LM3 being slightly more mature than the other two (1.2\% compared to $1.03-1.06 \%$ for LM1 and LM2). LM4, taken from a younger coal layer, has a lower vitrinite reflectance $(0.83 \%$; Table 2$)$. The three samples from the Carboniferous of Roujan-Neffiès show similar vitrinite reflectance values between $1.35 \%$ and $1.42 \%$ (medium volatile bituminous). Similar values were recorded for the Bosmoreau-les-Mines samples (1.37 and 1.43\%), which is in agreement with previous data of Becq-Giraudon and Mazeaud (1981). The coal from the Carboniferous of East Graissessac shows reflectance values between 1.2 and $1.48 \%$, which is in agreement with values recorded by Becq-Giraudon and Gonzalez (1986). These values indicate a coal rank between medium volatile bituminous 
and low volatile bituminous (Table 2). The coal from West Graissessac, is of a semianthracite rank as indicated by reflectance values of the order of $2 \%$.

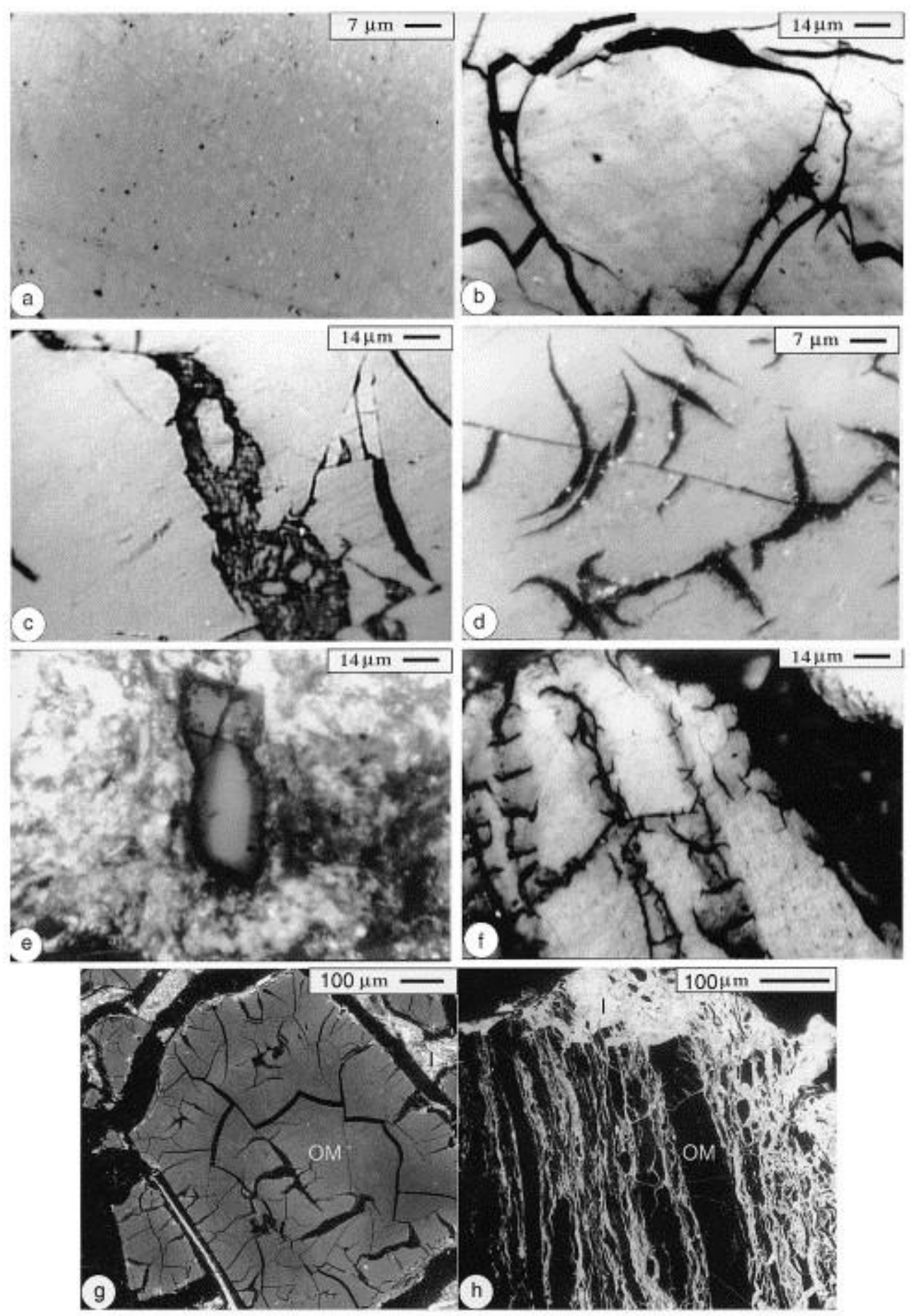

Fig. 2. (a) Telocollinite on which the Ro measurements were carried out (sample Mou1 from East Graissessac and Ro-Né2 from Roujan-Neffiès). (b) I-type microfracturing (sample Ro-Né1 from Roujan-Neffiès and Ber2 from Détroit de Rodez, southern boundary). (c) II-type microfracturing (sample Sé4.3 from East Graissessac). (d) III-type anastomosed microfracturing (sample RG2 from East Graissessac and A3 from Argentat). (e) $b$-type fringes with a lower reflectance (0.4\%) than the core $(0.6 \%)$ (sample A3' from Argentat). (f) $b$-type fringes ( $0.95 \%$ against $1.32 \%$ in the core) associated with anastomosed microfracturing (sample Sé2 from East Graissessac). (g) comparison of 
an oxidized particles, from Argentat (sample A3; (g)) with another one more oxidized, from East Graissessac (sample Sé1; (h)); OM: Organic Matter, 1: limestone; (SEM/BE photographs).

\subsection{Geochemistry}

The pyrolysis data presented in Table 2 highlight the marked diversity of the $T_{\max }$ values, as well as HI and OI. Only the $T_{\max }$ values will be considered in this section, and the reader is referred to the general discussion for the $\mathrm{HI}$ and OI values. Apart from a few abnormally high values (A3, $\mathrm{A}^{\prime}$ and Ber4: 560, 506 and $485^{\circ} \mathrm{C}$ ), the samples from the Argentat and Détroit de Rodez basins show $T_{\max }$ values between 435 and $450^{\circ} \mathrm{C}$, thus placing them in the first part of the oil window ( Espitalié et al., 1985a, Espitalié et al., 1985b and Espitalié et al., 1985c). It is noted, particularly for samples A3 and A3' from the Carboniferous of Argentat, that the high $T_{\max }$ values are associated with low HI and high OI values. The coal from the LapleauMaussac basin has $T_{\max }$ values between $470^{\circ} \mathrm{C}$ and $500^{\circ} \mathrm{C}$, which corresponds to the beginning of the gas window, i.e., during early metagenesis. The samples from East Graissessac can be divided into two sub-groups based on $T_{\max }$ values: (i) a first group with $T_{\max }$ values similar to those of Lapleau-Maussac $\left(480^{\circ} \mathrm{C}\right)$, (ii) a second group characterized by higher $T_{\max }$ values between 515 and $605^{\circ} \mathrm{C}$ which, as a first approximation, seems to suggest fairly varied maturity stages. In addition to their high $T_{\max }$ values, these samples also show relatively high OI values. The three samples from West Graissessac show homogeneous $T_{\max }$ values between 600 and $610^{\circ} \mathrm{C}$, suggesting a degree of maturity corresponding to the end of metagenesis. The $T_{\max }$ value of $533^{\circ} \mathrm{C}$ measured on coal sample Ro-Né3 from the Carboniferous of Roujan-Neffiès contrasts with the less mature samples Ro-Né1 and 2 from the same basin which have $T_{\max }$ values of about $482^{\circ} \mathrm{C}$, indicating the onset of metagenesis.

\subsection{Petrographic observations (optical microscope and SEM/BE)}

During the petrographic observations we particularly concentrated on characterizing the microfractures and studying the reflectance variations of the vitrinite particles. The following microfracture types were identified (Copard, 1998): (a) type I, mainly affecting vitrinite particles (Fig. 2b), (b) type II, larger than type I, affecting all samples studied, and commonly filled with clay, inertodetrinite, vitrodetrinite, and, in places, liptinite (Fig. 2c), and (c) type III, characterized by their specific anastomosed morphology, mainly affecting vitrinite particles (Fig. 2d). This type, which is only observed in samples with high OI values, represents microfracturing where high-temperature oxidation is likely to occur (Alpern and Maume, 1969). The first two microfracture types were observed in all the studied samples, whereas type III was only observed in samples A3 and A3' from Argentat, and Sé2, Sa1 and RG2 from East Graissessac. Certain vitrinite particles are characterized by fringes that are variably lighter than their cores. These fringes, following Copard (1998), are labelled $a$ where they have higher reflectance than the core of the vitrinite particle and $b$ where their reflectance is lower. $A$-type fringes may result from recent meteoric oxidation, whereas $b$-type fringes can be related to early oxidation during coal evolution as testified by Alpern and Maume (1969). $B$-type fringes (Fig. 2e) were identified in samples A1 and A3' $(0.4 \%$ in the fringes against $0.6 \%$ in the cores), LM1 and LM3 of Lapleau-Maussac (respectively $0.5 \%$ and $1 \%$ in the fringes against $1 \%$ and $1.3 \%$ in the cores), Ber 1 , Ber2 and Ber4' (0.5\% against $0.8 \%)$, Ay1 $(0.4 \%$ against $0.6 \%)$ and Sé2 and Sé4.3 (0.95-1\% against $1.32-1.46 \%)$. Furthermore, the $b$ type fringes observed in sample Sé2 were associated with III-type microfractures (Fig. 2f). 


\section{Discussion}

\subsection{Thermal activity}

As particularly demonstrated by the differences in paleo-heat flow evaluated in the Brive (100 and $120 \mathrm{~mW} \mathrm{~m}^{-2}$ ) and Bosmoreau-les-Mines (150 and $180 \mathrm{~mW} \mathrm{~m}^{-2}$ ) basins (Mascle, 1990 and Mascle, 1998), the Massif Central was subjected to a hyperthermal regime that varied in intensity from site to site. Such variations in the regional thermal field are closely linked to crustal thinning following thickening of the Variscan crust during the DevonianCarboniferous collisional episodes (Becq-Giraudon and Van Den Driessche, 1993; Faure, 1995). During thinning, the ductile-brittle limit in the crust must have been relatively close to the surface (10 km or less), as demonstrated by microthermometric studies carried out on fluid-inclusion planes in granites of the Haut Limousin (André, 1997). In addition to a decrease in the fluid-trapping depth, these analyses also suggest a drop in the homogenization pressure/temperature pair from Late Stephanian times, which continued through the Autunian. These results seem compatible with the marked decrease in temperature of the circulating hydrothermal fluids (from $350^{\circ} \mathrm{C}$ to $80-130^{\circ} \mathrm{C}$ ) recorded throughout the Massif Central between Stephanian-Autunian and Saxonian-Thuringian times (Jebrak, 1989). Modelling of the heat-flow evolution at the base of the sediments in the Brive basin indicates a marked decrease in the intensity of this flow from the Late Stephanian $\left(100-120 \mathrm{~mW} \mathrm{~m}^{-2}\right)$ to present day $\left(30 \mathrm{~mW} \mathrm{~m}^{-2}\right.$ ) (Mascle, 1998). According to this model, the immaturity of Lias organic matter in this basin can be explained not only by burial of the Mesozoic sediments to less than $1000 \mathrm{~m}$, but also by the low intensity of heat flow compared to that recorded during the Late Paleozoic. All these considerations are consistent with high geothermal paleogradient during the Late Carboniferous (Latouche, 1969; Becq-Giraudon and Gonzalez, 1986; BerquerGaboreau, 1986; Robert et al., 1988).

Recent studies (Ligouis, 1988; Wang, 1991; Disnar et al., 1995; Mascle, 1998) proposed an average paleoburial depth for the Stephanian successions of the order of $1500 \mathrm{~m}$, a depth which seems particularly applicable to the basins of Argentat, Bosmoreau-les-Mines, and Détroit de Rodez (Ligouis, 1988). We adopted this average paleoburial depth of $1500 \mathrm{~m}$ for the Stephanian successions of all the basins studied. On the base of previous results obtained on different basins such as Blanzy-Montceau (Golitsyn et al., 1997), Alès (Wang and Courel, 1993) and Graissessac (Becq-Giraudon and Gonzalez, 1986), the duration of coalification must have been rather short. It is difficult to give a precise figure but there are two geodynamic events which could have ended this evolution: (1) the Saalic orogenic phase ( $-270 \mathrm{Ma})$ which marks the Early/Late Permian boundary (Feys, 1989); in this case, the maximum coalification duration would have been 20-25 Ma. (2) The Palatine orogenic phase at the end of the Permian ( $-245 \mathrm{Ma}$ ) which would give a maximum coalification duration of 35-40 Ma.

Because, with the exception of samples A3 and A3' (Table 2), the $T_{\max }$ values recorded in the Détroit de Rodez and Argentat are very similar to those from the Brive basin, we adopted the thermal evolution model applied to the latter basin to the other two. The more mature Bosmoreau-les-Mines samples also seem to agree with the Brive basin model, although with higher heat flows (i.e., $150-180 \mathrm{~mW} \mathrm{~m}^{-2}$ at the base of the sediments, Mascle, 1998) during Stephanian-Autunian times.

The $T_{\max }$ values for the Lapleau-Maussac basin are relatively heterogeneous, varying from $470^{\circ} \mathrm{C}$ to $500^{\circ} \mathrm{C}$. Considering the intermediate maturity of those samples, located between that 
of Argentat, Détroit de Rodez and Bosmoreau-les-Mines, it is possible to envisage heat flows of between 120 and $140 \mathrm{~mW} \mathrm{~m}^{-2}$, with the $300 \mathrm{~m}$ difference in burial depth between LM4 and the surrounding lithostratigraphically deeper samples being sufficient to explain the difference in vitrinite reflectance $(0.83 \%$ vs. $1.05 \%$ - see Table 2$)$.

The Upper Paleozoic of Roujan-Neffiès was probably subjected, along with the basins of the Cévennes and Ardéche border (Wang and Courel, 1993; Disnar et al., 1995), to a hyperthermal regime. Estimation of the paleo-heat flow is nevertheless difficult due to the prevailing uncertainties concerning the history and burial of this basin. However, as the vitrinite reflectance values are identical to those of Bosmoreau-les-Mines (Table 2), we assume that the Roujan-Neffiès basin was probably subjected to a paleo-heat flow of the same order as that of Bosmoreau.

In the Graissessac basin, if we adopt a burial depth and coalification duration similar to those assumed previously, the degree of coal maturity depends essentially on the structural framework of the basin within which thermal domes developed and on the intensity of the heat flow associated with those domes. Their intensity seems directly linked to the endVariscan metamorphic cycle that affected the axial zone of the Montagne Noire to the southwest of the basin (Latouche, 1969; Becq-Giraudon and Gonzalez, 1986). Consequently, the thermal domes show increasing intensity the nearer they are to the axial zone. An increase in the coal rank from east to west (Table 3) confirms the spatial distribution and evolution of the intensity of these domes. The paleo-heat flows for West Graissessac are thus estimated at more than $180 \mathrm{~mW} \mathrm{~m}^{-2}$ by comparison with the situation in Bosmoreau-les-Mines. Adopting the same conditions, East Graissessac would have been subjected to flows corresponding to those of Lapleau-Maussac if based on $T_{\max }$, and those of Bosmoreau-les-Mines, if one considers vitrinite reflectance. 
Table 3. Coal ranks (ASTM standard) based on $R_{\mathrm{o}}$ and $T_{\max }$; anomalous samples are in bold

$\begin{array}{lcc}\left.\text { Basin and samples } \quad \text { Coal rank (based on } R_{0}\right) & \text { Coal rank (based on } \\ \left.T_{\max }\right)\end{array}$

Argentat (A1 and A2)

A3

A3'

Bosmoreau-les-Mines B1, B3

Lapleau-Maussac LM1, LM2

LM3

LM4

Détroit de Rodez (North)

Détroit de Rodez (South)

Ber4

Ber3 and Mé1

Roujan-Neffiès (Ro-Né1 and 2)

Ro-Né3

East Graissessac Sé1, 3, 4.1, 4.2, Medium-Volatile-

4.3, 5, RG1

RG2

Sé6, Mou1, Sa1'

Sé2, Roc-Camp1

Sa1

West Graissessac
High Volatile B Bituminous $\begin{aligned} & \text { High Volatile } \mathbf{C} \\ & \text { Bituminous }\end{aligned}$

High Volatile B

Bituminous

High Volatile B

Bituminous

Medium Volatile

Bituminous

High Volatile A

Bituminous

Medium-Volatile-

Bituminous

semi-anthracite

Low Volatile

Bituminous

semi-anthracite

Medium Volatile

Bituminous

Medium Volatile

Bituminous

High Volatile A Low Volatile

Bituminous

Bituminous

High Volatile B Bituminous

High Volatile $\mathbf{C}$

Bituminous

High Volatile B/A

Bituminous

High Volatile B/C

Bituminous

High Volatile A

Bituminous

Medium Volatile

Bituminous

High Volatile A

Bituminous

High Volatile B

Bituminous

Medium-Volatile-

Bituminous

Medium-Volatile-

Bituminous

Medium Volatile

Bituminous

Low-Volatile-

Bituminous

Medium-Volatile-

Bituminous

Bituminous

anthracite

Bituminous

Medium/Low Volatile

Bituminous

Low Volatile

Bituminous

Medium/Low Volatile

Bituminous

semi-anthracite

Medium/Low Volatile

Bituminous

anthracite

semi-anthracite

anthracite

Despite the various uncertainties concerning the results and/or their interpretation, there is no doubt that all the studied basins were subjected to a hyperthermal regime, probably controlled 
by basement faults dividing them into blocks. Knowledge of the hyperthermal activity thus mainly provides data concerning the tectonic regime at a given time. The Middle Permian Saalic orogeny is the most likely event responsible for interruption of the thermal maturation of the Stephanian coal studied. Local tectonic and erosion data make it possible to deduce a short lived coalification period, of $25 \mathrm{Ma}$ or less.

\subsection{Estimation of paleotemperatures recorded by organic matter}

Based on heat flow values and the assumed burial depth, the maximum paleotemperatures to which the coal was subjected can be estimated using the three methods described below and their results are presented and compared in Table 4.

Table 4. Comparison between results of the three methods used to characterize the maximum coal paleotemperatures

\begin{tabular}{|c|c|c|c|c|c|}
\hline Basin & $\begin{array}{c}\text { Average } \\
R_{0}(\%)\end{array}$ & Orogeny & $\begin{array}{l}\text { Method 1: } \\
\text { estimated } \\
\text { geothermal } \\
\text { gradient }\end{array}$ & $\begin{array}{c}\text { Method 2: based } \\
\text { on } R_{0} \text { (Karweil's } \\
\text { chart modified by } \\
\text { Bostick, 1971) }\end{array}$ & $\begin{array}{c}\text { Method 3: } \\
\text { based on } T_{\min } \\
\text { (Disnar, } \\
\text { 1994) }\end{array}$ \\
\hline Argentat & 0.65 & Saalic & $100 \pm 10^{\circ} \mathrm{C}$ & $110 \pm 10^{\circ} \mathrm{C}$ & $117 \pm 10^{\circ} \mathrm{C}$ \\
\hline $\begin{array}{l}\text { Détroit de } \\
\text { Rodez }\end{array}$ & 0.70 & Palatinian & $100 \pm 10^{\circ} \mathrm{C}$ & $90 \pm 10^{\circ} \mathrm{C}$ & $110 \pm 5^{\circ} \mathrm{C}$ \\
\hline \multirow[t]{2}{*}{$\begin{array}{l}\text { Lapleau- } \\
\text { Maussac }\end{array}$} & 1.05 & Saalic & $115 \pm 10^{\circ} \mathrm{C}$ & $140 \pm 10^{\circ} \mathrm{C}$ & $135 \pm 5^{\circ} \mathrm{C}$ \\
\hline & & Palatinian & $115 \pm 10^{\circ} \mathrm{C}$ & $115 \pm 10^{\circ} \mathrm{C}$ & $125 \pm 5^{\circ} \mathrm{C}$ \\
\hline $\begin{array}{l}\text { Bosmoreau } \\
\text { Neffiès }\end{array}$ & 1.40 & Saalic & $150 \pm 15^{\circ} \mathrm{C}$ & $155 \pm 10^{\circ} \mathrm{C}$ & $168 \pm 10^{\circ} \mathrm{C}$ \\
\hline $\begin{array}{l}\text { East } \\
\text { Graissessac }\end{array}$ & & Palatinian & $150 \pm 15^{\circ} \mathrm{C}$ & $125 \pm 10^{\circ} \mathrm{C}$ & $155 \pm 10^{\circ} \mathrm{C}$ \\
\hline \multirow[t]{2}{*}{$\begin{array}{l}\text { West } \\
\text { Graissessac }\end{array}$} & 2.00 & Saalic & $170 \pm 10^{\circ} \mathrm{C}$ & $180 \pm 10^{\circ} \mathrm{C}$ & $145 \pm 10^{\circ} \mathrm{C}$ \\
\hline & & Palatinian & $170 \pm 10^{\circ} \mathrm{C}$ & $150 \pm 10^{\circ} \mathrm{C}$ & $135 \pm 10^{\circ} \mathrm{C}$ \\
\hline
\end{tabular}

(1) The geothermal paleogradients prevailing during coalification was estimated, based on the heat flow values given previously and assuming an average thermal conductivity of $4 \times 10^{-3}$ cal cm $\mathrm{cm}^{-1} \mathrm{~s}^{-1} \mathrm{C}^{-1}$ for the sediments underlying the coal layers. The restrictions of this method are mainly related to the uncertainties concerning the paleo-heat flow extrapolated to the Lapleau-Maussac, Roujan-Neffiès and Graissessac basins. This flow is assumed to have been constant throughout coalification. Maximum burial, which was reached during the Late Paleozoic (Mascle, 1998), is assumed to be of the order of $1500 \mathrm{~m}$ for all the basins.

(2) This method is based on vitrinite reflectance values and on Karweil's time/temperature charts (modified by Bostick, 1971and in Robert, 1985) where the coalification period is 
assumed to be the same as the age of the coal. As the samples from any one basin were collected from lithostratigraphically well-defined horizons, it was possible to calculate average reflectance values for each basin (Table 4). Although we have reason to refute this model on the basis that it is too simple, since it obeys a single kinetic (Disnar, 1994), the model nevertheless can be used for comparative purposes as it is based on two samples from Ruhr (Germany) and an exponential law that is compatible with the normal evolution of vitrinite reflectance with depth (e.g., Bostick, 1971).

(3) The third method adopted for this study is based on determining the maximum paleotemperatures of burial (MPTB, Disnar, 1994) calculated from a kinetic parameter known as $T_{\min }$, that is graphically determined from the Rock-Eval S2 pyrolysis peak of OM (Disnar, 1994). An estimated value of a geological thermal gradient, expressed in ${ }^{\circ} \mathrm{C} \mathrm{Ma}^{-1}$. This geological gradient value is equal to the product of the classic geothermal gradient (in ${ }^{\circ} \mathrm{C}$ $\mathrm{km}^{-1}$ ) by the subsidence rate (in $\mathrm{km} \mathrm{Ma}^{-1}$ ).

The first two methods provided similar paleotemperatures for all the basins except the Lapleau-Maussac basin, which yields a lower paleotemperature using the first method (Table 4). The third method does not seem consistent with the other two, and only the MPTB values for Argentat and Détroit de Rodez seem comparable to the results of Karweil's method and the paleo-heat flow estimations. The high MPTB values for Bosmoreau-les-Mines are associated with samples showing a positive $T_{\max }$ anomaly and, consequently, $T_{\min }$. West Graissessac, however, has lower calculated MPTB values than those obtained with the other two methods, despite a positive $T_{\max }$ anomaly. In this case, the $\mathrm{S} 2$ pyrolysis peaks, which show marked asymmetry, cause the low $T_{\min }$ values and consequently the low MPTB values. The dissimilarity of the results obtained with three methods for the Lapleau-Maussac Basin can be explained by the scattered values of the maturity parameters, uncertainties concerning burial depth, the duration of coalification, and heat flow constant values.

\subsection{Relationship between the Au-As fluids and the heat flow affecting the Stephanian coal}

One of the initial aims of the present study was to determine whether the $\mathrm{Au}-\mathrm{As}$ fluids circulating during the Middle-Late Carboniferous (Roig et al., 1997) could have affected the Late Stephanian coals in the French Massif Central. At regional scale, a hydrothermal event is contemporaneous with an increased heat flow leading to the production of granite (Bouchot et al., 1997). Consequently, the $\mathrm{Au}$-As bearing fluids would, a priori, have been associated with episodes of magmatism and remobilization of the crust which occurred from 340 to $290 \mathrm{Ma}$ (Costa, 1990) and therefore could have influenced the Stephanian coals.

The heat flows, notably the most intense one, have two possible origins: (i) an extremely high geothermal paleogradient associated with a shallow ductile-brittle limit in the crust, and (ii) thermal metamorphism induced by basement metamorphic cycles which, through the creation of thermal domes of varying intensity, are likely to have had a direct effect on the sediments, as observed at Graissessac for example (Becq-Giraudon and Gonzalez, 1986); either origin not excluding the other.

According to the data provided herewith (Table 2 and Table 4) and the $T_{\max }$ values for coal determined by Mascle (1998); sites labelled 7-12 in Fig. 3), three basins, namely BosmoreauAhun, Meisseix and Graissessac (Fig. 3), show heat flows of above $160 \mathrm{~mW} \mathrm{~m}^{-2}$ for the Stephanian-Autunian. These areas are thus more likely to have been affected by the circulation of hydrothermal fluids. More specifically, it would seem that the high heat flow 
envisaged for Bosmoreau-Ahun is genetically related to the production of Variscan (340-290 Ma) granites in the Limousin (western part of Massif Central) and, more particularly, the Millevaches plateau (Ledru et al., 1994). This region would thus have had a shallow ductilebrittle limit in a hot crust, interpreted as a thermal dome of limited extent in the Limousin. By comparing the lowest ranks of Stephanian-Autunian coal in the northeast (Fig. 3. no. 8-9-10) and southwest (Brive-Argentat, Fig. 3. no. 12) of the Limousin with those of BosmoreauAhun, it is suggested that the peak of the hyperthermal event was confined to the Millevaches plateau. However, superposition of the As-Au anomalies and the heat flows onto the same map (Fig. 3) reveals no direct relationship between the emplacement of these two events. This is particularly true for the "hot zone" of the Limousin; the hydrothermal paleofields, responsible for As-Au mineralizations (Bouchot et al., 1997), appear to have developed along the edge of the Millevaches plateau, the hottest area of the Limousin dome. The discovery of gold-bearing pebbles in the Late Stephanian at Alès (Charrier, 1992) and in the Carboniferous at Argentat (Becq-Giraudon et al., 1999; Bouchot et al., 1999) confirms that these hydrothermal paleofields were active before the opening of the Stephanian-Autunian basins and, therefore, that these two events are not contemporaneous. 


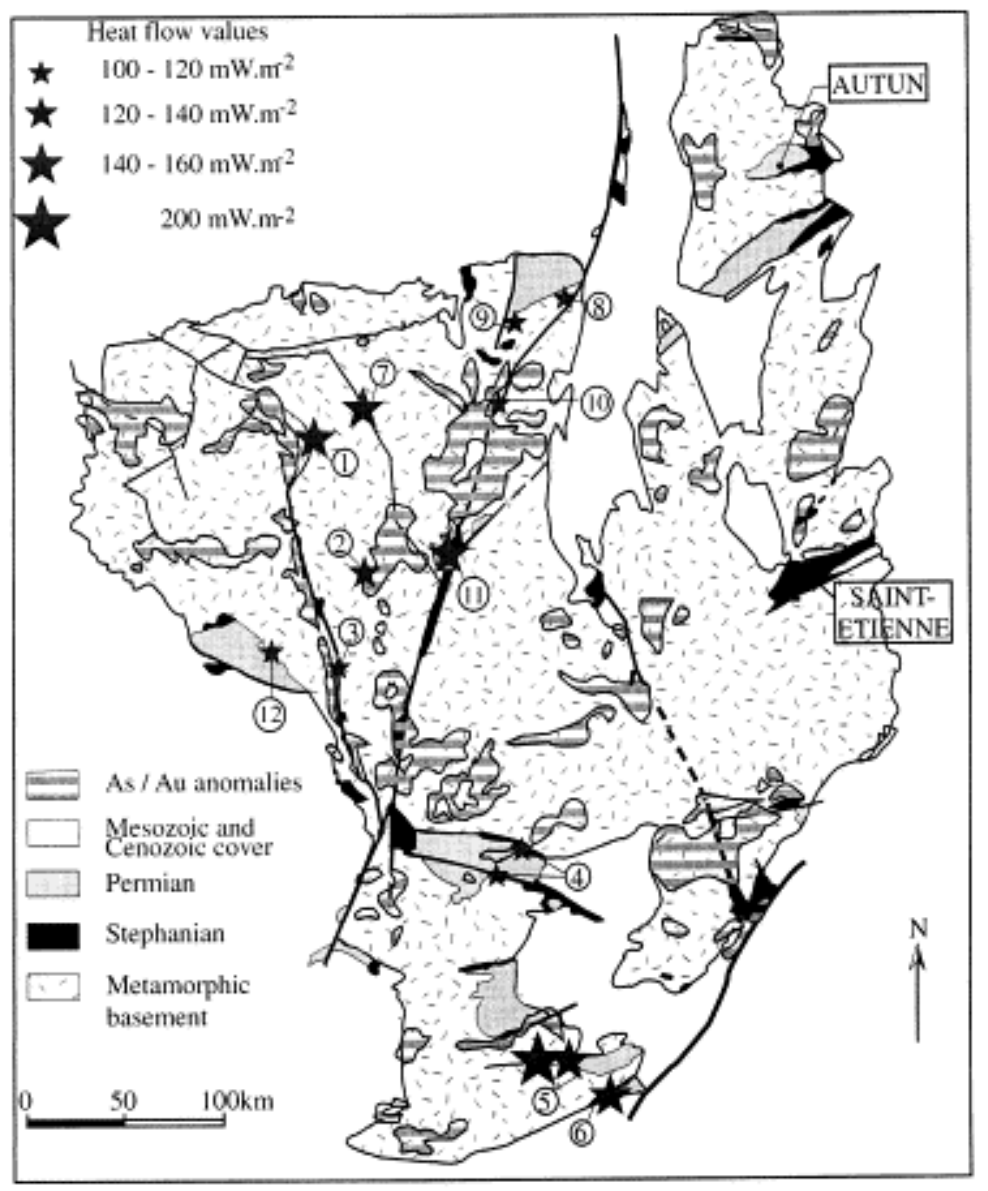

Fig. 3. General map of the Massif Central showing the location of the Carboniferous basins from which the analysed coal samples were collected (adapted from Becq-Giraudon, 1984). 1: Bosmoreaules-Mines, 2: Lapleau-Maussac, 3: Argentat, 4: Détroit de Rodez, 5: Graissessac, 6: Roujan-Neffiès, 7: Ahun, Saint-Michel-de-Veisse, 8 and 9: Noyant, 10: Saint-Eloy-les-Mines, 11: Meisseix, 12: Brives. Location of the hydrothermal paleofields (As anomaly $>80$ ppm, Bouchot et al., 1997); the stars correspond to the heat-flow intensities estimated during the present study — from the smallest to largest star: $100-120 \mathrm{~mW} \mathrm{~m}^{-2}, 120-140 \mathrm{~mW} \mathrm{~m}^{-2}, 160-180 \mathrm{~mW} \mathrm{~m}^{-2}, 200 \mathrm{~mW} \mathrm{~m}^{-2}$ (the heat flow rates for basins labelled 7 to 12 are derived from the $T_{\max }$ values adopted by Mascle, 1998).

\subsection{Anomalies typology}

Plotting of the results on HI/OI diagrams for each basin reveals OM evolution paths that differ from the standard evolution of a transformation under the influence of temperature (Fig. 4). The increase in the OI, accompanied by a decrease in the HI, suggests oxidation of the OM. 

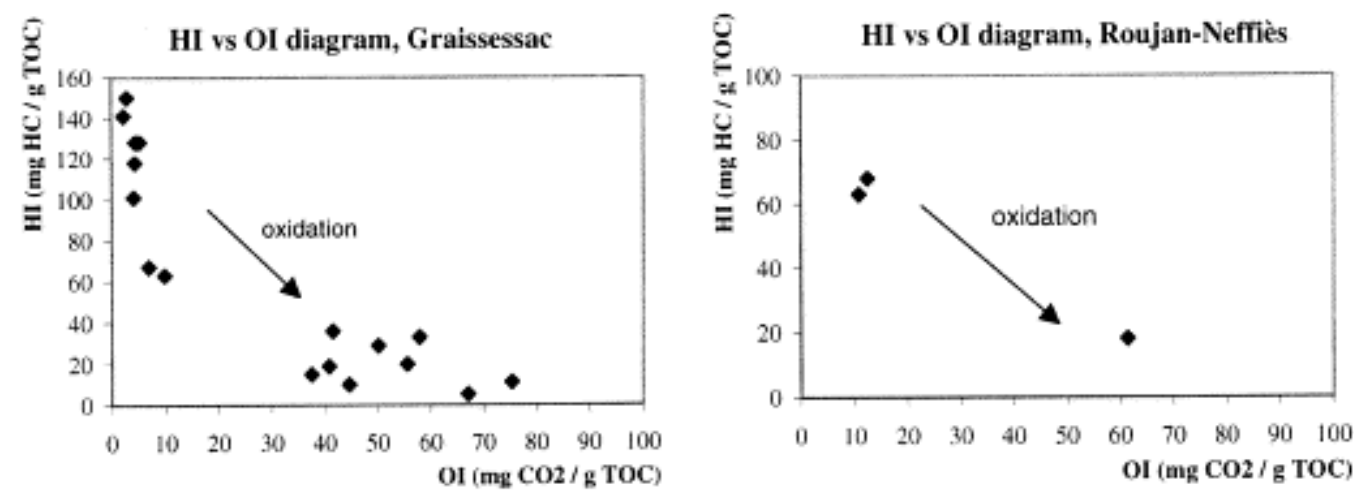

Fig. 4. Relationship between Hydrogen Index and Oxygen for samples from Graissessac and Roujan-Neffiès.

By plotting the results on a $R_{\mathrm{o}} / T_{\max }$ reference diagram (Fig. 5, adapted from Teichmüller and Durand, 1983), two groups of samples can be identified

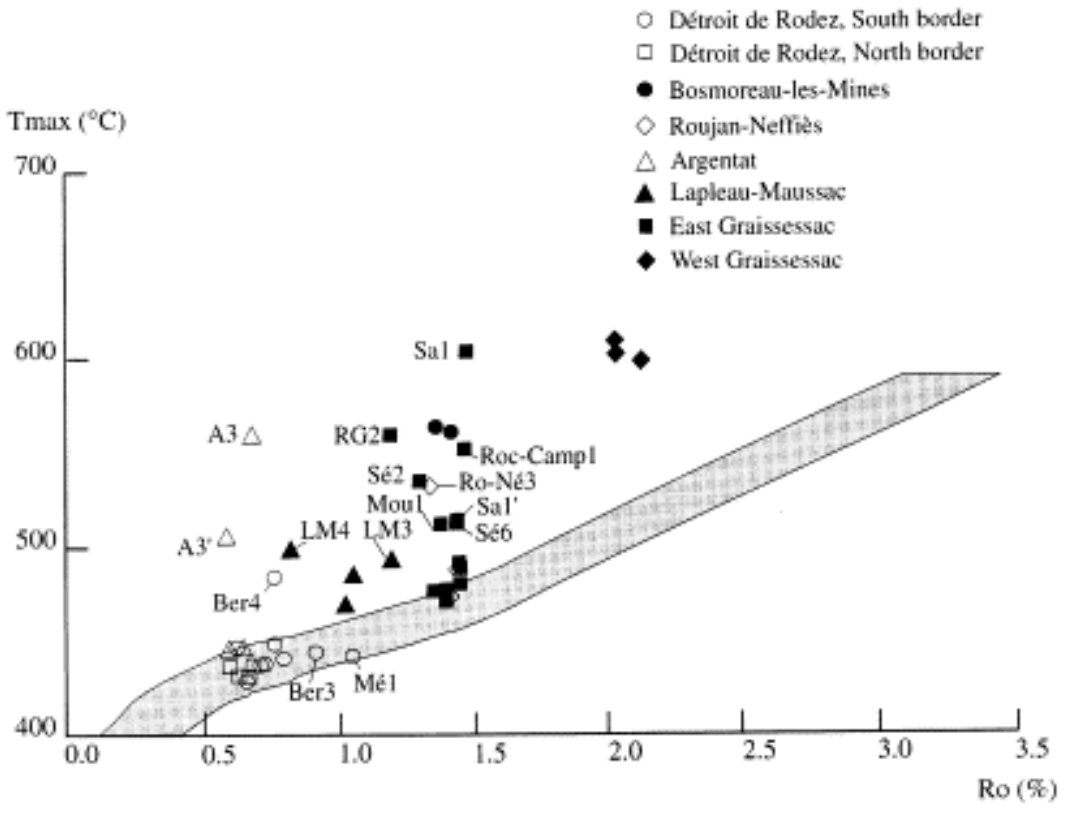

Fig. 5. $R_{\mathrm{o}} / T_{\max }$ diagram, the grey area corresponds to the $R_{\mathrm{o}} / T_{\max }$ correlation of Teichmüller and Durand (1983).

- A group near the $R_{0}-T_{\max }$ correlation curve (Fig. 5) comprising the Détroit de Rodez samples (except Ber4), A1 and A2 from Argentat, the East Graissessac samples (with a $T_{\max }<490^{\circ} \mathrm{C}$ ), and Ro-Né1 and 2 from Roujan-Neffiès. 
- A group characterized by abnormally high $T_{\max }$ values with respect to $R_{\mathrm{o}}$; these two parameters thus provide divergent information concerning the rank of a coal (Table 3). Based on the OI/ $T_{\max }$ diagram (Fig. 6), this group can be further subdivided into two sub-groups.

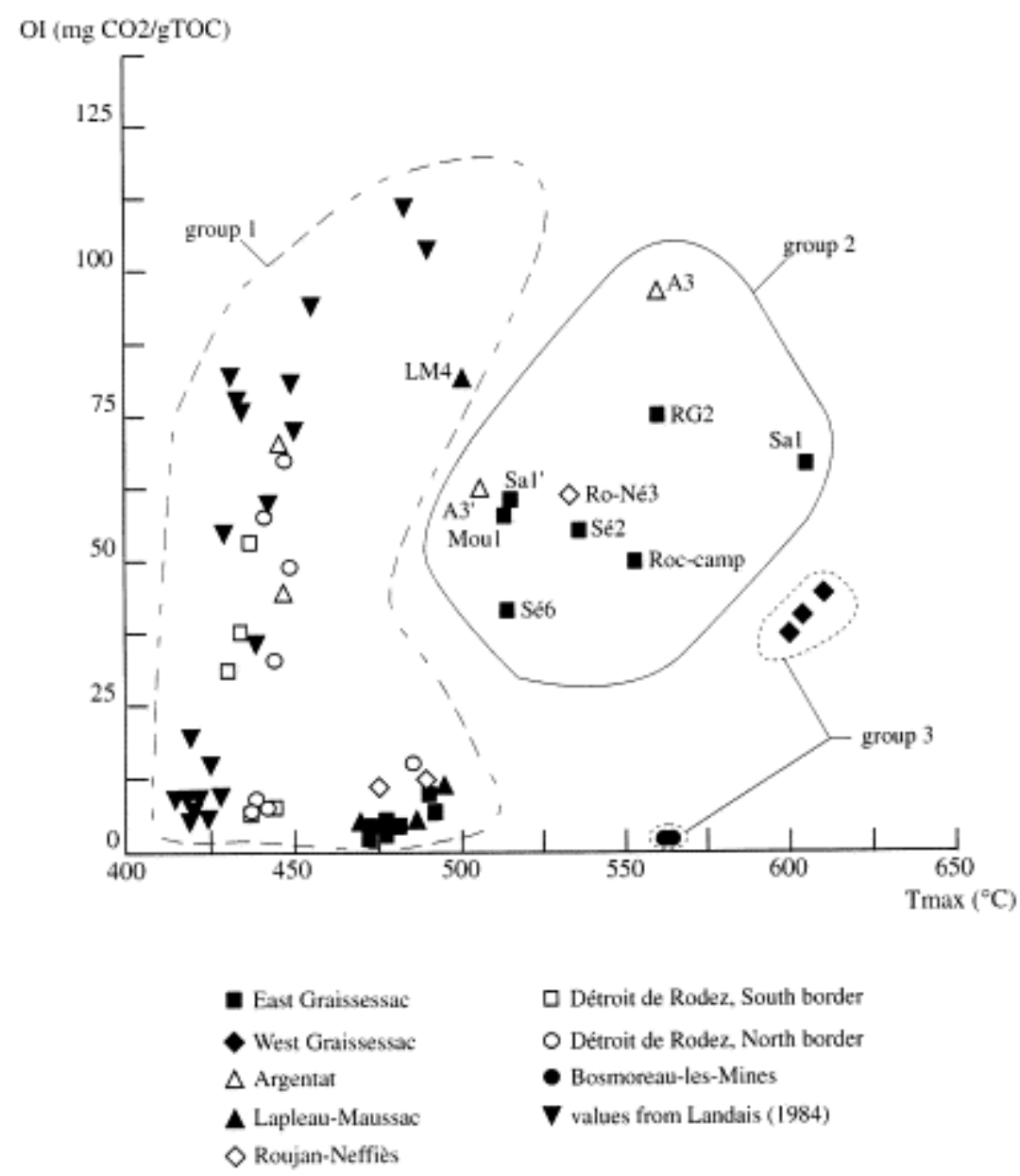

Fig. 6. OI/ $T_{\max }$ diagram including the values of Landais et al. (1984). Group 1: samples showing no significant $T_{\max }$ anomaly, Group 2: samples showing a positive $T_{\max } / \mathrm{OI}$ correlation, Group 3: samples showing a simple positive $T_{\max }$ anomaly with respect to the reference envelope of Teichmüller and Durand (1983), these samples belong to basins with a more intense hyperthermicity.

- Samples with diverging $R_{\mathrm{o}}$ and $T_{\max }$ accompanied by a positive $T_{\max } / \mathrm{OI}$ correlation (group 2, Fig. 6), particularly well represented by the East Graissessac samples (with a $T_{\max }>500^{\circ} \mathrm{C}$ ), and also by A3 and A3' of Argentat and Ro-Né3 of Roujan-Neffiès. This atypical anomaly can be attributed to the circulation of hot oxidizing fluids likely to cause a simultaneous increase in $T_{\max }$ and OI. Furthermore, the data suggest that the evolution of these two parameters can be associated with a slight decrease in $R_{0}$.

- Samples with a $R_{\mathrm{O}} / T_{\max }$ divergence but no notable increase in OI (group 3, Fig. 6), represented by the Bosmoreau-les-Mines and West Graissessac samples. This $R_{\mathrm{o}} / T_{\max }$ 
divergence, without any sign of oxidation, probably has a purely thermal origin and consequently, the $T_{\max }$ anomaly probably becomes more marked with increasing intensity of the local heat flow.

These two types of anomalies $\left(R_{0} / T_{\max }\right.$ alone and $\left.R_{0} / T_{\max } / \mathrm{OI}\right)$ seem to be superimposed onto the classic thermal maturation process of coal, a priori similar to burial diagenesis, which distorts the interpretation of the parameters considered independently.

A synthesis of the results acquired for the Lapleau-Maussac basin (Table 2) seems difficult to interpret because of a large scatter in $R_{0}, T_{\max }$ and OI values. However, samples LM1 and LM2 are similar to those of Bosmoreau-les-Mines, inasmuch as they have a high $T_{\max }$ (compared to $R_{\mathrm{O}}$ ), but not necessarily a high OI. Sample LM3, from the same stratigraphic layer as LM1 and LM2, but with a higher $R_{0}$, nevertheless poses a problem. The presence of $b$-type fringes suggests that this sample underwent early oxidation (Alpern and Maume, 1969), which had the effect of modifying the reflectance and, to a lesser degree, $T_{\max }$, but not the OI (Copard, 1998).

\subsection{Origin of the $T_{\max } / \mathrm{OI}$ and $R_{0} / T_{\max }$ anomalies}

The textural and $R_{\mathrm{o}}$ observations make it possible to exclude alteration related to plutonic intrusion, which would have considerably increased $R_{\mathrm{o}}$ (Goodarzi and Cameron, 1990; Bertrand and Pradier, 1993). Similarly, late meteoric oxidation, as observed in certain samples, is likely to cause an increase in the OI, but not $T_{\max }$ (Deroo, 1986).

\subsection{1. $\mathrm{T}_{\max } /$ OI anomaly}

Fluid circulation can cause variably complex modifications of OM, with the nature and intensity being governed by fluid temperature and composition, and by the rank of the coal at the onset of the hydrothermal event. Harouna et al. (1993) attributed a marked increase in reflectance, a classic evolution of $T_{\max }$ with burial and a decrease in the $\mathrm{H} / \mathrm{C}$ ratio without variation of the $\mathrm{O} / \mathrm{C}$ ratio, to the influence of early diagenetic hydrothermal flows of moderate temperature, i.e., too low for the cracking of OM, thus a variation in $T_{\max }$. We can exclude such syn-coalification hydrothermal circulation because the $T_{\max }$ of our samples collected from a single lithostratigraphic unit from the same basin should be constant. Furthermore, the high paleo-heat flow that is assumed to have affected the entire Massif Central during the Stephanian-Autunian is not consistent with the circulation of early hydrothermal fluids of moderate-temperature.

We thus envisage late hydrothermal flows probably during and due to the tectonic event affecting the French Massif Central during Upper Carboniferous and Lower Permian. We assume that the fluids were of a higher temperature than that reached during coalification. An increase in $T_{\max }$ is only possible if the coal receives sufficient heat to break the molecular bonds that show increased stability with increasing OM maturity (Disnar, 1994). However, the increase in $T_{\max }$ that the hot fluids would have caused should be accompanied by a decrease in the OI, as with a classic maturation process, which is not observed here. We can rule out coal alteration by low-temperature fluids, a process essentially reflected by an increase in the OI (Fig. 6; Landais et al., 1984) which is similar comparable to simple oxidation of meteoric type. However, if the fluids involved had been of a moderate oxidizing nature in addition to having a high temperature, they would have probably caused coal transformations identical to those observed. The reasons why this moderately oxidizing 
thermal event was not recorded by $R_{\mathrm{o}}$ remain to be determined. Two hypotheses can be proposed based on the constancy of the $R_{\mathrm{o}}$ values for the same basin:

(1) According to the Fresnel-Beer formula, the loss of aliphatic chains, which could lead to a thermal maturation process, tends to decrease the refraction index $\mathrm{n}$ and thus increase $R_{\mathrm{o}}$. Conversely, coal oxidation causes the formation of ether, carbonyl and hydroxyl groups (Berkowitz, 1979, van Krevelen, 1981) that have higher molecular refraction indices than the aromatic bonds. We can thus assume that the influence of temperature and oxidation can contradict each other and cause no notable $R_{\mathrm{o}}$ variation.

(2) If we consider the artificial maturation experiments of Monthioux (1986) and Saxby et al. (1986), $R_{\mathrm{o}}$ seems to evolve very slowly under the influence of temperature. Furthermore, George (1992)observed a delay in $R_{\mathrm{o}}$ evolution with respect to that of $T_{\max }$ as one approaches a volcanic dyke; the $R_{\mathrm{o}}$ evolution kinetics thus seem slower than those of $T_{\max }$ where the OM is subjected to intense thermal events such as dyke intrusion. In our case, the anomalous coal may not have recorded notable $R_{\mathrm{o}}$ variations during a hyperthermal event, providing that it was of fairly short duration. This process would have occurred after coalification, which agrees fairly well with a reflectance of the altered coal identical to those of the surrounding coal.

The most feasible hypothesis to explain most of the anomalies observed is one involving the circulation of hot, moderately oxidizing fluids after coalification. The presence of $b$-type fringes, marking an alteration of vitrinite particles, does not seem to indicate widespread oxidation of this maceral. Conversely, the III-type microfractures that affect the samples with highly anomalous $T_{\max }$ and OI (A3, RG2, Sé2 and Sa1) seem to constitute a criterion of hightemperature OM oxidation. In addition, the SEM results confirm that the more oxidized the sample, the denser the fracture system is (Fig. 2g). The hydrothermal circulation hypothesis, although probable, was not confirmed by the presence of typical minerals.

\subsection{2. $\mathrm{R}_{o} / \mathrm{T}_{\max }$ anomaly}

The abnormally high $T_{\max }$ values compared to $R_{\mathrm{o}}$, without an increase in the OI, were particularly well represented in the Bosmoreau-les-Mines and West Graissessac basins. Both these sites show extremely high heat flows between $150 \mathrm{~mW} \mathrm{~m}^{-2}$ and $200 \mathrm{~mW} \mathrm{~m}^{-2}$. The results of the artificial maturation experiments mentioned above suggest a difference in the evolution rate of $R_{\mathrm{o}}$ and $T_{\max }$. In addition, in the Rhine Graben, Doebl et al. (1974)noted abnormally low vitrinite reflectance values considering the current regional thermal activity. Along the Ardéche margin, carbonaceous debris in a Rhaetian layer affected by hydrothermal circulation gave a $R_{\mathrm{o}}$ of $1.57 \%$ and an abnormally high $T_{\max }$ value of $539^{\circ} \mathrm{C}$ against the expected $480^{\circ} \mathrm{C}$ (Disnar et al., 1997). All these examples point towards the hypothesis that the identified anomalies may result from the reflectance evolution kinetics being slower than those of $T_{\max }$.

\section{Conclusions}

- All the studied basins record a hyperthermal event of variable intensity related to the geodynamic conditions prevailing in the Variscan belt during the Stephanian-Autunian. The most intense paleo-heat flows, such as those of the Millevaches plateau (Bosmoreau-Ahun), are probably related to a very hot crust with a shallow ductile-brittle limit and the development of thermal domes of varying extent. The local tectonic and erosion data suggest 
that the Saalic orogeny (Early/Late Permian boundary) is the most likely event responsible for interruption of coalification of the analysed coal.

- The absence of superposition of the hydrothermal paleofields and the heat flows estimated from the maturity of the Stephanian coal reveals that no direct relationship exists between these two events. The discovery of gold-bearing pebbles at Argentat and Alès confirms that gold mineralization occurred before opening of the basins, and the $-300 \mathrm{Ma}$ age (Bouchot et al., 1997) proposed for gold emplacement in the Massif Central thus corresponds to the youngest age for this event.

- The petrographic $\left(R_{\mathrm{o}}\right)$ and geochemical (pyrolysis: $\left.T_{\max }, \mathrm{OI}, \mathrm{HI}\right)$ analyses have made it possible to identify two types of anomalies that seem to be superimposed on coal maturation and are characterized by either a divergence in the evolution of $R_{\mathrm{O}}$ and $T_{\max }$ associated with a high OI, or by a simple divergence between $R_{\mathrm{o}}$ and $T_{\max }$ for the same sample. The first type indicates a local thermal and oxidizing character at sample scale, whereas the second reflects a hyperthermal event at regional scale.

We propose two hypotheses for the origin of these anomalies:

(a) $R_{\mathrm{O}} / T_{\max }$ divergence associated with a positive OI anomaly, based on the assumption that hot, slightly oxidizing fluids circulated after coalification.

(b) $R_{\mathrm{o}} / T_{\max }$ divergence associated with very high hyperthermal activity at basin scale, or better still, tectonic-block scale, interpreted as a first-order chemical reaction velocity differential between $R_{\mathrm{o}}$ and $T_{\max }$.

- Type III anastomosed microfractures, notably observed at Graissessac and Argentat, optically characterize the positive OI anomaly in association with a high $T_{\max }$.

- In summary, this study demonstrates a difference in reaction kinetics for $R_{\mathrm{o}}$ and $T_{\max }$ that is related, to varying degrees, to hyperthermal activity affecting a lithologic column under given geodynamic conditions. Interpretation of the observations is thus faced with the problem of oxidation of the coal at different temperatures and the consequences concerning the rank parameters and the reliability for their combined use as maturity indicators. In this respect, if the increase in reflectance is very slow compared to that of $T_{\max }$, it is the latter that more accurately reflects the true rank of the sample.

\section{Acknowledgements}

The authors would like to thank Jim Hower, Maria Mastalertz and Paul Robert for their careful rereading of the manuscript which greatly benefitted from their constructive criticisms. This paper is assigned the BRGM scientific contribution no. 99004 and the Géofrance 3D Program no. 57.

\section{References}

Alpern and Maume, 1969

B Alpern, F Maume

Etude pétrographique de l'oxydation naturelle et artificielle des houilles

Rev. Ind. Miner., 51 (11) (1969), pp. 979-998 
André, 1997

André, A.S., 1997. Paléochamps de contraintes et paléochamps géothermiques, Exemple des granites tardihercyniens du Nord du Limousin. DEA dissertation, Laboratoire d'Etude des Systèmes Hydrothermaux, University of Nancy, 1, 39 pp.

Becq-Giraudon and Gonzalez, 1986

J.F Becq-Giraudon, G Gonzalez

Maturation de la matière organique dans le bassin stéphanien de Graissessac

(Hérault): liaison entre structure et métamorphisme des charbons; signification régionale, note brève

Géol. France, 3 (1986), pp. 339-344

Becq-Giraudon and Mazeaud, 1981

Becq-Giraudon, J.F., Mazeaud, N., 1981. Bassin houiller de Bosmoreau-les-Mines

(Creuse), étude géologique. BRGM Report, 81, SGN 291 GEO, 47 pp.

Becq-Giraudon and Van Den Driessche, 1993

J.F Becq-Giraudon, J Van Den Driessche

Continuité de la sédimentation entre le Stéphanien et l'Autunien dans le bassin de Graissessac-Lodève (sud du Massif Central): implications tectoniques

C.R. Acad. Sci. Paris, 317 (1993), pp. 939-945 Série II

Becq-Giraudon et al., 1999

Becq-Giraudon, J.F., Roig, J.Y., Bouchot, V., Milési, J.P., 1999. Internal palaeogeography of the Uer Carboniferous (Stephanian) outliers of Argentat (Massif Central, France):

Metallogenic Implications (Géofrance 3D). Submitted to EUG, 1999.

Berkowitz, 1979

Berkowitz, N., 1979. An Introduction to Coal Technology. In: Denton, J. (Ed.), Energy Science and Engineering: Resources, Technology, Management. Academic Press, New York, $346 \mathrm{pp}$.

Berquer-Gaboreau, 1986

Berquer-Gaboreau, Cl., 1986. Pétrologie des charbons de deux bassins limniques du Massif Central français (Blanzy-Montceau et Meisseix). Exemples d'hyperthermies locales. Doctoral thesis, Univ. Lille, 184 pp.

Bertrand and Pradier, 1993

Bertrand, P., Pradier, B., 1993. Optical methods applied to source rock study. In:

Bordenave, M.L. (Ed.), Applied Petroleum Geochemistry. Technip, Paris, pp. 281-310.

Bostick, 1971

N.H Bostick

Thermal alteration of clastic organic particles as an indicator of contact and burial metamorphism in sedimentary rocks 
Am. Assoc. Stratigr. Palynologists Proc., 2nd, Geoscience Man., 3 (1971), pp. 8392

Bouchot et al., 1997

V Bouchot, J.P Milési, J.L Lescuyer, P Ledru

Les minéralisations aurifères de la France dans leur cadre géologique autour de $300 \mathrm{Ma}$

Chron. Rech. Min, 528 (1997), pp. 13-62

Bouchot et al., 1999

V Bouchot, J.F Becq-Giraudon, L Bailly, E Le Goff, J.P Milési

Identification of palaeoconglomerate-hosted $\mathrm{Au}-\mathrm{As}$ bearing pebbles in the

Stephanian Argentat basin: geological implications

J. Conf. Abs., 4 (1999), p. 478

Charrier, 1992

Charrier, J., 1992. Etude des minéralisations aurifères des Cévennes (Massif Central, France) et de leur contexte géologique. Doctoral thesis, Univ. Limoges, unpublished, 271 pp.

Copard, 1998

Copard, Y., 1998. Contribution à la mise en évidence depaléocirculations des fluides dans les bassins houillers du Massif Central français par l'analyse de la Matière Organique.

BRGM Report GF3D, 94/98, 83 pp.

Costa, 1990

Costa, S., 1990. De la collision continentale à l'extension tardi-orogénique: 100 millions d'années d'histoire varisque dans le Massif Central français. Une étude chronologique par la méthode 40 Ar-39 Ar. Doctoral thesis, University of Languedoc, Montpellier, 391 pp.

Deroo, 1986

Deroo, G., 1986. Altération superficielle de la Matière Organique. IFP Internal Report, unpublished.

Disnar, 1994

J.R Disnar

Determination of maximum paleotemperatures of burial (MPTB) of sedimentary rocks from pyrolysis data on the associated organic matter: basic principles and practical application

Chemical Geology, 118 (1994), pp. 289-299

Disnar et al., 1995

Disnar, J.R., Barsonny, I., Drouet, J., Espitalié, J., Farjanel, G., Marquis, F., Martinez, L., 1995. Géochimie organique et reconstitution de l'histoire thermique et tectonosédimentaire de la marge ardéchoise (programme GPF; France). In: Résumé des communications de la Séance spécialisée de la S.G.F., du sédiment...au réservoir, 
quantification et modélisation de la diagenèse, 6 and 7 November 1995, Poitiers, pp. 7381.

Disnar et al., 1997

J.R Disnar, F Marquis, J Espitalié, I Barsonny, S Drouet, D Giot

Géochimie organique et reconstitution de l'histoire thermique et tectono-

sédimentaire de la marge ardéchoise (programme GPF; France)

Bull. Soc. Géol. France, 168 (1) (1997), pp. 73-81

Doebl et al., 1974

Doebl, F., Heling, D., Homann, W., Karweil, J., Teichmüller, M., Welte, D., 1974.

Diagenesis of Tertiary clayey sediments and included dispersed organic matter in

relationship to geothermics in the upper Rhine Graben. In: Approaches to Taphrogenesis,

Inter-Union Commission of Geodynamics Scientific Report, Stuttgart 1974, pp. 192-207.

Espitalié et al., 1985a

J Espitalié, G Deroo, F Marquis

La pyrolyse Rock-Eval et ses applications

Rev. Inst. Franç. du Pétr., 40 (5) (1985), pp. 563-579

Espitalié et al., 1985b

J Espitalié, G Deroo, F Marquis

La pyrolyse Rock-Eval et ses applications

Rev. Inst. Franç. du Pétr., 40 (6) (1985), pp. 755-784

Espitalié et al., 1985c

J Espitalié, G Deroo, F Marquis

La pyrolyse Rock-Eval et ses applications

Rev. Inst. Franç. du Pétr., 41 (1) (1985), pp. 73-89

Faure, 1995

M Faure

Late orogenic Carboniferous extensions in the Variscan French Massif Central

Tectonics, 14 (1) (1995), pp. 132-153

Faure and Becq-Giraudon, 1993

M Faure, J.F Becq-Giraudon

Sur la succession des épisodes extensifs au cours du désépaississement carbonifère du Massif Central français

C.R. Acad. Sci. Paris, 316 (1993), pp. 967-973 série II

Faure et al., 1997

M Faure, C Leloix, J.Y Roig

L'évolution polycyclique de la chaîne hercynienne

Bull. Soc. Géol. France, 168 (6) (1997), pp. 695-705

Feys, 1989

Feys, R., 1989. Le système permien en Europe. In: Synthèse Géologique des Bassins

Permiens Français. Mém. BRGM 128, 17-22, Orléans. 
Gelard et al., 1986

J.P Gelard, C Castaing, D Bonijoly, J Grolier

Structure et dynamique de quelques bassins houillers limniques du Massif Central

Mém. Soc. Géol. France, N.S., 149 (1986), pp. 57-72

Genna et al., 1998

A Genna, J.Y Roig, P.J Debriette, V Bouchot

Le bassin houiller d'Argentat (Massif Central français), conséquence

topographique d'un plissement de son substratum varisque

C.R. Acad. Sci. Paris, 327 (1998), pp. 279-284

George, 1992

S.-C George

Effect of igneous intrusion on the organic geochemistry of a siltstone and an oil shale horizon in the Midland Valley of Scotland

Org. Geochem., 18 (5) (1992), pp. 705-713

Golitsyn et al., 1997

A Golitsyn, L Courel, P Debriette

A fault-related coalification anomaly in the Blanzy-Montceau Coal Basin (Massif Central, France)

Int. J. Coal. Geol., 33 (1997), pp. 209-228

Goodarzi and Cameron, 1990

F Goodarzi, A.R Cameron

Organic petrology and elemental distribution in thermally altered coals from

Telkwa, British Columbian

Energy Sources, 12 (1990), pp. 315-343

Harouna et al., 1993

M Harouna, J.-R Disnar, L Martinez, J Trichet

Discrepancies between different organic maturity indicators in a coal series

affected by an abnormal thermal event (Visean, Niger)

Chemical Geology, 106 (1993), pp. 397-413

Jebrak, 1989

Jebrak, M., 1989. Le thermalisme au Permien. In: Synthèse Géologique des Bassins Permiens Français. Mém. BRGM 128, 265-270, Orléans.

Lafargue et al., 1996

Lafargue, E., Espitalié, J., Marquis, F., Pillot, D., 1996. ROCK EVAL 6 applications in hydrocarbon exploration, production and in soil contamination studies. Conference proceedings: 5th Latin American Congress on Organic Geochemistry, Cancun, October 6$10,26 \mathrm{pp}$.

Landais et al., 1984

P Landais, M Monthioux, J.-D Meunier

Importance of the oxidation/maturation pair in the evolution of humic coals 
Org. Geoch., 7 (3/4) (1984), pp. 249-260

Latouche, 1969

L Latouche

Existence d'un métamorphisme post-stéphanien dans le bassin de Graissessac et dans la partie nord-est de la zone axiale de la Montagne Noire (Hérault)

C.R. Somm. Soc. Géol. Fr., 3 (1969), pp. 93-94

Ledru et al., 1994

Ledru, P., Costa, S., Echtler, H., 1994. Structure. In: Keppies, J.D. (Ed.), Pre-Mesozoic

Geology in France and related areas. Springer-Verlag, Berlin, pp. 305-323.

Leloix, 1998

Leloix, C., 1998. Arguments pour une évolution polycyclique de la chaîne hercynienne, structure des Unités Dévono-dinantiennes du Nord-Est du Massif Central (Brévenne-

Bourbonnais-Morvan). Doctoral thesis, Univ. Orléans, 248 pp.

Letourneur, 1953

L Letourneur

Le Grand Sillon Houiller du plateau central français

Bull. Carte. Géol. France, LI, 238 (1953), pp. 12-36

Ligouis, 1988

Ligouis, B., 1988. La grande couche de Bourran du bassin stéphanien de Decazeville (Aveyron), Pétrologie et environnements de dépôt du charbon: genèse d'une veine puissante. Doctoral thesis, Univ. Orléans, $341 \mathrm{pp}$.

Marest, 1985

Marest, D., 1985. Comparaison des évolutions dynamiques des bassins houillers limniques du Limousin: mise en place de modèle de dépôts. Doctoral thesis, Univ. Paris, $268 \mathrm{pp}$.

Mascle, 1990

A Mascle

Géologie pétrolière des bassins permiens français. Comparaison avec les bassins permiens du Nord de l'Europe

Chron. Rech. Min., 499 (1990), pp. 69-86

Mascle, 1998

Mascle, A., 1998. Subsidence et thermicité des bassins stéphano-permiens de l'Ouest du Massif Central, rapport provisoire. BRGM Report GF3D, 93/98, 16 pp.

Monthioux, 1986

Monthioux, M., 1986. Maturation naturelle et artificielle d'une série de charbons homogènes. Doctoral thesis, Univ. Orléans, 331 pp. 
Robert, 1985

Robert, P., 1985. Histoire géothermique et diagenèse organique. Bull. Centres Rech. Explor-Prod. Elf-Aquitaine, Dissertation, 345 pp.

Robert et al., 1988

P Robert, C Berquer, L Courel, B Kubler, P Robert

Anomalie thermique précoce dans le bassin houiller stéphanien de Meisseix-

Singles, Massif Central français

Sci. Géol. Bull., 3/4 (1988), pp. 333-349

Roig et al., 1997

J.Y Roig, P Calgano, V Bouchot, H Maluski, M Faure, l'équipe Géofrance 3D

Cartographie et Métallogénie du Massif Central

Modélisation 3D du paléochamp hydrothermal As+Au (330-300 Ma) le long de la faille d'Argentat (Massif Central français)

Chron. Rech. Min., 528 (1997), pp. 63-69

Saxby et al., 1986

J.-D Saxby, A.J.R Bennett, J.F Corcoran, D.E Lambert, K.W Riley

Petroleum generation: simulation over six years of hydrocarbon formation from torbanite and brown coal in a subsiding basin

Org. Geochem., 9 (2) (1986), pp. 69-81

Teichmüller and Durand, 1983

M Teichmüller, B Durand

Fluorescence microscopical rank studies on liptinites and vitrinites in peat and coals, and comparison with results of the Rock-Eval pyrolysis

Int. J. Coal Geol., 2 (1983), pp. 197-230

van Krevelen, 1981

van Krevelen, D.W., 1981. Coal chemistry, the main chemical reaction processes of coal.

In: Coal Science and Technology 3. Coal, typology — chemistry — physics -

constitution. Elsevier, pp. 155-236.

Wang, 1991

Wang, H., 1991. Dynamique sédimentaire, structuration et houillification dans le bassin houiller stéphanien des Cévennes. Doctoral Thesis, University of Bourgogne, Dijon, 266 pp.

Wang and Courel, 1993

H Wang, L Courel

Houillification dans le bassin houiller stéphanien des Cévennes (France)

Zbl. Geol. Paläont. Teil I, 5 (1993), pp. 473-486 